\title{
Effects of dietary fish oil and flax seed on cholesterol and fatty acid composition of egg yolk and blood parameters of laying hens
}

\author{
H. Basmacioğlü ${ }^{1 \#}$, M. Çabuk ${ }^{2}$, K. Ünal ${ }^{3}$, K. Özkan ${ }^{1}$, S. Akkan ${ }^{1}$ and H. Yalçın ${ }^{3}$ \\ ${ }^{1}$ Ege University, Faculty of Agriculture, Department of Animal Science, Bornova-İzmir, Turkey \\ ${ }^{2}$ Celal Bayar University, Vocational School, Department of Poultry Science, Akhisar, Manisa-Turkey \\ ${ }^{3}$ Ege University, Faculty of Engineering, Department of Food Engineering, Bornova-İzmir, Turkey
}

\begin{abstract}
This study was conducted to determine the effects of the supplementation of different levels of fish oil (FO) and flax seed (FS) in the diets of layers on the content of egg yolk fatty acid, cholesterol, blood parameters, egg production and egg quality criteria. In the experiment, a total of 120 Isa-White laying hens of 34 weeks of age were used. Hens were divided randomly into five groups and fed different diets containing no FO and FS; $1.5 \%$ FO; $4.32 \%$ FS; $1.5 \%$ FO+4.32\% FS and 8.64\% FS for eight weeks. A significant decrease in yolk cholesterol content (mg/g yolk) was found in the eggs from hens fed the diets containing $1.5 \%$ FO and $8.64 \%$ FS as compared with the control. Adding FO and FS to diets significantly increased the total omega-3 fatty acids in eggs at 28 (phase 1) and 56 (phase 2) days of the trial. By contrast, the addition of both FO and FS to diets had no effect on total omega- 6 fatty acids in eggs in phase 1 . But dietary $1.5 \% \mathrm{FO}, 4.32 \% \mathrm{FS}$ and $1.5 \% \mathrm{FO}+4.32 \% \mathrm{FS}$ supplementation decreased significantly the total omega- 6 fatty acids compared to the controls in phase 2 . The linolenic acid content of eggs was the highest in eggs from hens fed the diet with added FS, while docosahexaenoic acid content was the highest in eggs from hens fed diets with added FO. Dietary supplementation of FO and FS did not significantly affect the concentrations of serum trigliceride and high density lipoprotein. The serum cholesterol level of hens fed diets containing $1.5 \% \mathrm{FO}+4.32 \% \mathrm{FS}$ and $8.64 \% \mathrm{FS}$ was lower than the control group. The addition of FO and FS to diets did not cause any negative effect on some egg quality criteria such as egg weight, yolk weight, yolk ratio, albumen weight, albumen ratio, shell weight, shell ratio, shell strength and shell thickness. The egg production of hens fed a diet containing $4.32 \%$ FS was significantly higher than the controls. Feed intake and feed conversion were not affected by all treatments.
\end{abstract}

Keywords: Omega-3 fatty acids, cholesterol, eggs, flax seed, fish oil

${ }^{\#}$ Corresponding author. E-mail: basmacioglu@ziraat.ege.edu.tr

\section{Introduction}

The egg is one of the most complete foods from a nutritional point of view. However, consumers refrain from egg consumption due to the relatively high cholesterol content of eggs and the perception that cholesterol rich foods lead to coronary heart disease (CHD) and atheriosclerosis (Zeidler, 1998). Risk factors for CHD include hypertension, obesity and elevated blood cholesterol concentrations. The occurrence of CHD was higher in humans who have high blood cholesterol levels. Nutrition, genetics, age and sex affect blood cholesterol levels in humans. During the past 20 years public concern has focused on the relationship between dietary cholesterol and the development of CHD. However, dietary fat type and fatty acid composition of fats consumed, are more important than the amount of dietary cholesterol consumed (Leskanich \& Noble, 1997; Simopoulos, 2000b). According to the results of many studies, it was confirmed that saturated fatty acids and trans fatty acids cause negative effects on human health, but polyunsaturated fatty acids (PUFA) have a positive effect on human health as regards CHD (Blanch \& Grashorn, 1995; Bhatnagar \& Durrington, 2003; Erkkila et al., 2003; Meyer et al., 2003). In recent years, consumer demands for more healthy foods stimulated the interest in modifying the fatty acid profile of eggs. Over the past 20 years many studies and clinical investigations revealed that omega-3 PUFA, particularly eicosapentaenoic (EPA) and docosahexaenoic (DHA) exert beneficial effects on human health. Omega-3 PUFA are essential for normal growth and development and many play an important role in the prevention and treatment of CHD, hypertension, inflammatory, autoimmune disorders and cancer (Meluzzi et al., 1997a; Lewis et al., 2000; Simopoulos, 2000a). Eggs and poultry meat rich in omega-3 fatty acids can be produced by using feed ingredients rich in omega-3 fatty acids. In general, studies have been conducted to determine the effects of different omega-3 fatty acids sources in diets on the cholesterol and fatty acid composition of egg yolk and 
meat (Caston \& Leeson, 1990; Cherian \& Sim, 1991; Hammershøj, 1997; Coetzee \& Hoffman, 2002; Komprda et al., 2003). However, studies with regard to the effects of omega-3 fatty acids on blood cholesterol are lacking. In addition, in many studies the most important criteria such as egg yolk cholesterol and fatty acid content of eggs, blood cholesterol, the performance of layers and egg quality criteria were not fully determined (Caston \& Leeson, 1990; Cherian \& Sim, 1991; Jiang et al., 1991; Herber \& Van Elswyk, 1996; Hammershøj, 1997; Niemiec et al., 1997).

In this study, the effects were studied of adding fish oil and flax seed to layers diets on the cholesterol and fatty acid content of egg yolk, blood parameters, the performance of layers and egg quality criteria.

\section{Materials and Methods}

One hundred and twenty 34-week old Isa-White laying hens were randomly allocated to five experimental treatments. Each treatment consisted of six replications, with a replication consisting of four hens in a cage. The cages were kept in an open-sided layer house and the experiment lasted for eight weeks. The experimental diets were: A control diet (C) containing no fish oil (FO) or flax seed (FS); treatment FO containing $1.5 \%$ fish oil; treatment FS1 containing 4.32\% flax seed; treatment FO+FS with $1.5 \%$ fish oil $+4.32 \%$ flax seed and treatment FS2 containing $8.64 \%$ flax seed. The 4.32 and $8.64 \%$ FS were added to provide 1.5 and $3.0 \%$ flax seed oil to the respective diets. The experimental diets were formulated to be isoenergetic (11.5 MJ ME $/ \mathrm{kg} \mathrm{DM}$ ) and isonitrogenous (16.5\% crude protein). The ingredient and chemical composition of the experiment diets are presented in Table 1 and their fatty acid composition in Table 2.

Table 1 The ingredient and chemical composition of the experimental diets (as fed)

\begin{tabular}{|c|c|c|c|c|c|}
\hline & $\mathrm{C}$ & FO & FS1 & $\mathrm{FO}+\mathrm{FS}$ & FS2 \\
\hline \multicolumn{6}{|l|}{ Ingredients (kg/1000 kg) } \\
\hline Maize & 604.8 & 539.0 & 526.8 & 497.3 & 484.5 \\
\hline Soybean meal & 191.2 & 183.3 & 177.8 & 156.6 & 153.6 \\
\hline Cotton seed meal & 95.8 & 100 & 76.4 & 125 & 97.7 \\
\hline Wheaten bran & 7.4 & 56.5 & 80.3 & 59.7 & 84.1 \\
\hline Flax seed & - & - & 43.2 & 43.2 & 86.4 \\
\hline Sawdust & 10 & 6.5 & 5.6 & 0.3 & - \\
\hline Fish oil & - & 15 & - & 15 & - \\
\hline Limestone & 67.3 & 78.3 & 69.0 & 80.0 & 73.9 \\
\hline Dicalcium phosphate & 16.9 & 14.6 & 14.1 & 16.1 & 13.1 \\
\hline Salt & 2.8 & 2.9 & 2.8 & 2.8 & 2.7 \\
\hline Mineral Premix ${ }^{*}$ & 2 & 2 & 2 & 2 & 2 \\
\hline Vitamin Premix ${ }^{* *}$ & 1.0 & 1.0 & 1 & 1 & 1 \\
\hline DL-Methionine $(0.98)$ & 0.8 & 1 & 1 & 1.0 & 1 \\
\hline Total & 1000 & 1000 & 1000 & 1000 & 1000 \\
\hline \multicolumn{6}{|l|}{ Composition, g/kg (analysed) } \\
\hline Dry matter & 906.3 & 911.6 & 909.4 & 915.5 & 914.3 \\
\hline Crude protein & 164.9 & 163.1 & 164.1 & 162.8 & 166.0 \\
\hline Ether-extract & 30.3 & 42.6 & 44.4 & 57.5 & 58.5 \\
\hline Crude cellulose & 43.8 & 43.4 & 42.0 & 43.4 & 47.7 \\
\hline Crude ash & 108.9 & 116.3 & 108.8 & 121.9 & 126.9 \\
\hline $\begin{array}{l}\text { Apparent metabolisable energy, } \\
\mathrm{MJ} / \mathrm{kg} \text { feed }\end{array}$ & 11.47 & 11.43 & 11.45 & 11.57 & 11.57 \\
\hline Total calcium & 35.6 & 39.0 & 38.0 & 38.7 & 39.1 \\
\hline Total phosphorus & 7.4 & 7.2 & 7.2 & 7.7 & 7.4 \\
\hline Lysine (calculated) & 7.9 & 7.9 & 7.7 & 7.9 & 7.7 \\
\hline Met.+Cys. (calculated) & 5.7 & 5.7 & 5.7 & 5.7 & 5.7 \\
\hline
\end{tabular}

C: Control: without fish oil and flax seed; FO: with $1.5 \%$ fish oil; FS1: with $4.32 \%$ flax seed; FO+FS: with $1.5 \%$ fish oil + $4.32 \%$ flax seed; FS2: with $8.64 \%$ flax seed

*Mineral premix (mg/kg diet): $\mathrm{Mn}-80 ; \mathrm{Fe}-60 ; \mathrm{Zn}-60 ; \mathrm{Cu}-5$; Co - 0.2; I - 1; Se - 0.15

**Vitamin premix (/kg diet): Vitamin A - $12000 \mathrm{IU}$; vitamin $\mathrm{D}_{3}$ - $2000 \mathrm{IU}$; vitamin $\mathrm{E}$ - $35 \mathrm{IU}$; vitamin $\mathrm{K}_{3}$ - $5 \mathrm{mg}$; vitamin $\mathrm{B}_{1}$ - $3 \mathrm{mg}$; choline chloride - $350 \mathrm{mg}$; vitamin $\mathrm{B}_{2}-6 \mathrm{mg}$; niacin - $20 \mathrm{mg}$; calcium D-pantothenate - $6 \mathrm{mg}$; vitamin $\mathrm{B}_{6}-5$ $\mathrm{mg}$; vitamin $\mathrm{B}_{12}-0.015 \mathrm{mg}$; folic acid - $0.75 \mathrm{mg}$; D-biotine - $0.045 \mathrm{mg}$; vitamin C - $50 \mathrm{mg}$ 
Table 2 The fatty acid composition of the control and experimental diets (percentage of total fatty acids)

\begin{tabular}{|c|c|c|c|c|c|}
\hline Fatty acid & $\mathrm{C}$ & FO & FS1 & $\mathrm{FO}+\mathrm{FS}$ & FS2 \\
\hline $\mathrm{C}_{14: 0}$ myristic & 0.55 & 2.66 & 0.50 & 2.68 & 0.12 \\
\hline $\mathrm{C}_{16: 0}$ palmitic & 10.59 & 13.32 & 9.78 & 10.39 & 8.14 \\
\hline $\mathrm{C}_{16: 1}$ palmitoleic & 0.14 & 3.05 & 0.15 & 2.29 & 0.15 \\
\hline $\mathrm{C}_{18: 0}$ stearic & 2.29 & 2.94 & 3.35 & 3.29 & 3.48 \\
\hline $\mathrm{C}_{18: 1}$ oleic & 26.51 & 23.06 & 21.99 & 21.43 & 20.86 \\
\hline $\mathrm{C}_{18: 2 \mathrm{n}-6}$ linoleic & 57.57 & 39.29 & 41.38 & 31.81 & 34.00 \\
\hline $\mathrm{C}_{18: 3 \mathrm{n}-3}$ linolenic & 2.35 & 2.74 & 22.85 & 18.87 & 33.25 \\
\hline $\mathrm{C}_{18: 4 \mathrm{n}-3}$ stearidonic & - & 0.87 & - & 0.61 & - \\
\hline $\mathrm{C}_{20: 4 \mathrm{n}-6}$ arachidonic & - & 0.27 & - & 0.30 & - \\
\hline $\mathrm{C}_{20: 5 \mathrm{n}-3}$ eicosapentaenoioic & - & 3.53 & - & 2.70 & - \\
\hline $\mathrm{C}_{22: 5 \mathrm{n}-3}$ docosapentaenoic & - & 0.49 & - & 0.34 & - \\
\hline $\mathrm{C}_{22: 6 n-3}$ docosahexaenoic & - & 6.78 & - & 5.25 & - \\
\hline$\sum$ Saturated & 13.43 & 18.92 & 13.63 & 15.59 & 11.74 \\
\hline $\bar{\sum}$ Unsaturated & 86.57 & 80.08 & 86.37 & 83.64 & 88.26 \\
\hline$\sum$ omega-3 & 2.35 & 14.68 & 22.85 & 25.64 & 56.90 \\
\hline$\sum$ omega-6 & 57.57 & 39.56 & 41.38 & 32.11 & 14.62 \\
\hline$\sum$ omega-6/omega-3 & 24.50 & 2.69 & 1.81 & 1.25 & 0.26 \\
\hline
\end{tabular}

C: Control: without fish oil and flax seed; FO: with $1.5 \%$ fish oil; FS1: with $4.32 \%$ flax seed; FO+FS: with $1.5 \%$ fish oil + $4.32 \%$ flax seed; FS2: with $8.64 \%$ flax seed

To determine cholesterol and fatty acid content of egg yolk, six eggs were collected after 28 days (phase 1) and after 56 days (phase 2) from each treatment. In order to determine serum cholesterol, triacylglycerol and high density lipoprotein (HDL) concentrations, a total of 30 blood samples (six samples per group) were taken from the wing vein, after feed withdrawal for $12 \mathrm{~h}$. After coagulation, the blood was centrifuged at $2000 \mathrm{rpm}$ to obtain the serum. The serum parameters were analysed by auto analyzer (Opera technicon ${ }^{\circledR}$ ), using commercial kits (Sigma Diagnostic ${ }^{\circledR}$ Kits). A direct saponification procedure was applied for the analysis of cholesterol in egg samples (Poyraz, 1987). Lipids were extracted from eggs using the method of the AOAC (1990). The fatty acid methyl esters were prepared from lipid samples according to Joseph \& Ackman (1992) and from subsequent fatty acid profiles obtained by gas liquid chromatography (GLC). The fatty acid methyl esters were analysed using a $50 \times 0.25 \mathrm{~mm}$ inside diameter WCOT fused silica CP-Sil 88 capillary column installed in a Hewlett Packard 5890 GLC with flame ionization detector. Egg production was recorded daily and calculated as hen-day (\%). Feed consumption (g/hen/day) and feed conversion as $\mathrm{kg}$ feed consumed/kg eggs were recorded at 28 and 56 days of the trial. Egg quality criteria (egg weight, yolk weight, yolk ratio, albumen weight, albumen ratio, shell weight, shell ratio, shell strength and shell thickness) were measured at 28 days and 56 days of the trial, using 18 eggs from each experimental unit. Mortality was recorded daily. The standard techniques for the Proximate analysis were used to determine the nutrient concentrations in the diets (Naumann \& Bassler, 1993). The experimental diets were analysed also for starch, sugar, total calcium and phosphorus, according to VDLUFA method (Naumann \& Bassler, 1993). Metabolisable energy content of the diets was calculated based on their chemical composition (Anonymous, 1991). The data were analysed statistically using the General Linear Models procedure of SAS (1985). Significant differences between treatment means were separated using the Duncan's multiple range test with a $5 \%$ probability.

\section{Results and Discussion}

The cholesterol contents in both the egg yolk and eggs of layers decreased significantly $(\mathrm{P}<0.05)$ with increasing age (Table 3). The finding that cholesterol content of egg yolk in layers decreased with increasing age agrees with the findings of previous research (Oltjen \& Dinius, 1975; Gissel et al., 1976; Brendl et al., 1979; Basmacioğlu \& Ergül, 2000). It was previously reported that the cholesterol content in eggs increased with age and this increase resulted from an increase in both egg and yolk weights (Oltjen \& Dinius, 1975; Basmacıŏlu \& Ergül, 2000).

A significant decrease in yolk cholesterol concentration $(\mathrm{mg} / \mathrm{g}$ yolk) was found in the eggs from the hens receiving the diets containing $1.5 \%$ FO and $8.64 \%$ FS as compared with the control. Lin \& Pratt (1992) reported that when omega-3 fatty acid rich 3\% menhaden oil was added to the diet, yolk cholesterol 
concentration (mg/g yolk) decreased by $15 \%$. In addition, it was reported that fish oil (Meluzzi et al. 1997b) or flax seed (Caston \& Leeson, 1990) did not effect the egg yolk cholesterol concentration (mg/egg). Our results (Table 3 ) agree with these findings.

Table 3 The effect of adding fish oil (FO) and flax seed (FS) to the diet on the concentration of cholesterol in the egg yolk

\begin{tabular}{lcc}
\hline & \multicolumn{2}{c}{ Egg yolk cholesterol } \\
\cline { 2 - 3 } Treatments & $\mathrm{mg} / \mathrm{g}$ yolk & $\mathrm{mg} / \mathrm{egg}$ \\
\hline $\mathrm{C}$ & $13.71^{\mathrm{ab}}$ & 205.42 \\
FO & $12.56^{\mathrm{c}}$ & 198.75 \\
FS1 & $13.93^{\mathrm{a}}$ & 219.20 \\
FO + FS & $13.51^{\mathrm{abc}}$ & 211.07 \\
FS2 & $12.79^{\mathrm{c}}$ & 202.00 \\
\hline SEM & $0.335^{\mathrm{a}}$ & 7.558 \\
\hline Phase 1 & $14.15^{\mathrm{a}}$ & $218.28^{\mathrm{a}}$ \\
Phase 2 & $12.46^{\mathrm{b}}$ & $196.29^{\mathrm{b}}$ \\
SEM & $0.212^{-}$ & 4.780 \\
\hline & Significance \\
\hline Treatment & $*$ & $\mathrm{NS}$ \\
Phase & $* *$ & $* *$ \\
Treatment $x$ Phase & $* *$ & $\mathrm{NS}$ \\
\hline C: Contr: With
\end{tabular}

C: Control: without fish oil and flax seed; FO: with 1.5\% fish oil; FS1: with $4.32 \%$ flax seed; FO+FS: with $1.5 \%$ fish oil + $4.32 \%$ flax seed; FS2: with $8.64 \%$ flax seed

${ }^{\mathrm{a}, \mathrm{b}, \mathrm{c}}$ Means in the same column with the same superscript do not differ $(\mathrm{P}>0.05)$

** $\mathrm{P}<0.01 ; *: \mathrm{P}<0.05 ; \mathrm{NS}$ - not significant $(\mathrm{P}>0.05)$

$\mathrm{SEM}=$ standard error of the mean

Table 4 The effect of including fish oil (FO) and flax seed (FS) in a layer diet on the fatty acid composition of egg yolk at day 28 of the trial

\begin{tabular}{|c|c|c|c|c|c|c|c|}
\hline Fatty acids ${ }^{1}$ & $\mathrm{C}$ & FO & FS1 & $\mathrm{FO}+\mathrm{FS}$ & FS2 & SEM & Significance \\
\hline $\mathrm{C}_{14: 0}$ & $0.33^{c}$ & $0.48^{b}$ & $0.26^{\mathrm{d}}$ & $0.53^{\mathrm{a}}$ & $0.22^{d}$ & 0.016 & $* *$ \\
\hline $\mathrm{C}_{16: 0}$ & $26.33^{a}$ & $25.80^{\mathrm{ab}}$ & $24.13^{c}$ & $25.07^{b c}$ & $22.06^{\mathrm{d}}$ & 0.375 & $* *$ \\
\hline $\mathrm{C}_{16: 1}$ & $3.19^{\mathrm{ab}}$ & $3.57^{\mathrm{a}}$ & $3.01^{b c}$ & $3.28^{\mathrm{ab}}$ & $2.65^{\mathrm{c}}$ & 0.123 & $* *$ \\
\hline $\mathrm{C}_{18: 0}$ & $9.01^{\mathrm{a}}$ & $8.22^{b}$ & $9.05^{\mathrm{a}}$ & $8.96^{\mathrm{a}}$ & $9.46^{\mathrm{a}}$ & 0.199 & $* *$ \\
\hline $\mathrm{C}_{18: 1}$ & 38.29 & 39.30 & 37.50 & 35.54 & 37.72 & 0.863 & NS \\
\hline $\mathrm{C}_{18: 2 \mathrm{n}-6}$ & 17.22 & 16.24 & 18.02 & 17.74 & 17.65 & 0.665 & NS \\
\hline $\mathrm{C}_{18: 3 n-3}$ & $0.62^{\mathrm{d}}$ & $0.71^{\mathrm{d}}$ & $3.49^{c}$ & $4.00^{\mathrm{b}}$ & $5.89^{\mathrm{a}}$ & 0.124 & $* *$ \\
\hline $\mathrm{C}_{18: 4 \mathrm{n}-3}$ & $0.20^{\mathrm{a}}$ & $0.16^{\mathrm{b}}$ & $0.16^{\mathrm{b}}$ & $0.13^{b}$ & $0.15^{b}$ & 0.012 & $* *$ \\
\hline $\mathrm{C}_{20: 4 n-6}$ & $2.25^{\mathrm{a}}$ & $1.13^{\mathrm{d}}$ & $1.52^{b}$ & $0.91^{\mathrm{e}}$ & $1.36^{\mathrm{c}}$ & 0.042 & $* *$ \\
\hline $\mathrm{C}_{20: 5 n-3}$ & - & $0.18^{b}$ & $0.06^{\mathrm{d}}$ & $0.26^{\mathrm{a}}$ & $0.12^{c}$ & 0.009 & $* *$ \\
\hline $\mathrm{C}_{22: 5 \mathrm{n}-3}$ & $0.07^{\mathrm{b}}$ & $0.19^{\mathrm{a}}$ & $0.17^{\mathrm{a}}$ & $0.21^{\mathrm{a}}$ & $0.22^{\mathrm{a}}$ & 0.015 & $* *$ \\
\hline $\mathrm{C}_{22: 6 \mathrm{n}-3}$ & $0.65^{\mathrm{d}}$ & $3.29^{\mathrm{a}}$ & $1.70^{\mathrm{c}}$ & $2.90^{\mathrm{b}}$ & $1.98^{\mathrm{c}}$ & 0.108 & $* *$ \\
\hline$\sum$ saturated & $35.67^{\mathrm{a}}$ & $34.50^{b}$ & $33.44^{\mathrm{c}}$ & $34.56^{b}$ & $31.74^{\mathrm{d}}$ & 0.375 & $* *$ \\
\hline$\sum$ omega-3 & $1.54^{\mathrm{e}}$ & $4.53^{\mathrm{d}}$ & $5.58^{\mathrm{c}}$ & $7.50^{\mathrm{b}}$ & $8.36^{\mathrm{a}}$ & 0.204 & $* *$ \\
\hline$\sum$ omega-6 & 19.47 & 17.37 & 19.54 & 18.65 & 19.01 & 0.688 & NS \\
\hline$\sum$ omega-6/omega- 3 & $12.64^{\mathrm{a}}$ & $3.83^{b}$ & $3.50^{\mathrm{b}}$ & $2.49^{c}$ & $2.27^{\mathrm{c}}$ & 0.289 & $* *$ \\
\hline
\end{tabular}

C: Control: without fish oil and flax seed; FO: with $1.5 \%$ fish oil; FS1: with $4.32 \%$ flax seed; FO+FS: with $1.5 \%$ fish oil + $4.32 \%$ flax seed; FS2: with $8.64 \%$ flax seed

${ }^{1} \%$ of total fatty acid; $\quad{ }^{\mathrm{a}, \mathrm{e}}$ Row means with common superscripts do not differ $(\mathrm{P}>0.05)$

$* * \mathrm{P}<0.01 ; * \mathrm{P}<0.05 ; \mathrm{NS}-$ not significant $(\mathrm{P}>0.05)$

Fatty acid composition of eggs obtained at the end of the first phase is given in Table 4, while that obtained at the end of the second phase of the trial is summarized in Table 5. Adding FO and FS to the diets significantly increased the amount of total omega-3 fatty acids in both phases. The total saturated fatty acids decreased in both phases of the experiment, and was significant $(\mathrm{P}<0.05)$ except for layers fed the $1.5 \% \mathrm{FO}$ in phase 1. Total omega-3 fatty acid concentrations increased more in eggs obtained from layers fed both FO

The South African Journal of Animal Science is available online at http://www.sasas.co.za/Sajas.html 
and FS than those fed either FO or FS. A five fold increase $(\mathrm{P}<0.05)$ in the concentration of DHA in eggs was recorded when the hens received the diet containing $1.5 \%$ FO, compared to the control diet. These results were similar to those reported by Caston \& Leeson (1990), Cherian \& Sim (1991), Hargis et al. (1991), Scheideler \& Froning (1996), Gonzalez-Esquerra \& Leeson (2000) and Meluzzi et al. (2000). The highest levels of linolenic acid, which is also a omega-3 fatty acid, were detected in eggs of layers fed the diets containing FS. Due to the increase in omega-3 fatty acids and decrease in omega- 6 fatty acids in eggs, the ratio of omega-6/omega-3 in eggs was reduced from 12.64 to 2.27 at day 28 of the trial and from 14.56 to 2.28 at day 56.

Adding FO and FS to the diets did not affect the total omega- 6 fatty acid content of yolk at day 28 of the trial. Dietary supplementation of $1.5 \% \mathrm{FO}, 4.32 \% \mathrm{FS}$ and $1.5 \% \mathrm{FO}+4.32 \% \mathrm{FS}$ decreased $(\mathrm{P}<0.05)$ the concentration of total omega- 6 fatty acids of yolk compared to controls at day 56 of the trial. Jiang et al. (1991) found that there were no significant changes in the total omega-6 fatty acid content of yolk at a dietary inclusion of $15 \% \mathrm{FS}$, compared to their control.

Table 5 The effect of including fish oil (FO) and flax seed (FS) in a layer diet on the fatty acid composition of egg yolk at day 56 of trial

\begin{tabular}{|c|c|c|c|c|c|c|c|}
\hline Fatty acids ${ }^{1}$ & $\mathrm{C}$ & FO & FS1 & $\mathrm{FO}+\mathrm{FS}$ & FS2 & SEM & Significance \\
\hline $\mathrm{C}_{14: 0}$ & $0.31^{b}$ & $0.48^{\mathrm{a}}$ & $0.23^{c}$ & $0.45^{\mathrm{a}}$ & $0.22^{c}$ & 0.013 & $* *$ \\
\hline $\mathrm{C}_{16: 0}^{14.0}$ & $25.92^{a}$ & $25.48^{a}$ & $23.12^{b}$ & $23.91^{b}$ & $21.33^{\mathrm{c}}$ & 0.302 & $* *$ \\
\hline $\mathrm{C}_{16: 1}^{10.0}$ & $2.95^{\mathrm{b}}$ & $3.47^{\mathrm{a}}$ & $3.06^{\mathrm{b}}$ & $3.17^{\mathrm{b}}$ & $2.50^{\mathrm{c}}$ & 0.084 & $* *$ \\
\hline $\mathrm{C}_{18: 0}$ & 9.19 & 8.92 & 8.53 & 8.68 & 9.17 & 0.197 & NS \\
\hline $\mathrm{C}_{18: 1}^{10.0}$ & $37.46^{\mathrm{ab}}$ & $39.14^{\mathrm{ab}}$ & $40.37^{\mathrm{a}}$ & $36.21^{\mathrm{b}}$ & $36.20^{\mathrm{b}}$ & 1.003 & $*$ \\
\hline$C_{18: 2 n-6}^{10.1}$ & $19.08^{a}$ & $16.29^{b}$ & $17.16^{\mathrm{b}}$ & $17.04^{b}$ & $19.44^{\mathrm{a}}$ & 0.581 & $* *$ \\
\hline $\mathrm{C}_{18: 3 n-3}$ & $0.56^{\mathrm{c}}$ & $0.71^{\mathrm{c}}$ & $3.23^{b}$ & $3.60^{\mathrm{b}}$ & $6.66^{\mathrm{a}}$ & 0.180 & $* *$ \\
\hline$C_{18: 4 n-3}$ & $0.21^{\mathrm{a}}$ & $0.15^{\mathrm{bc}}$ & $0.14^{\mathrm{c}}$ & $0.14^{\mathrm{c}}$ & $0.18^{\mathrm{ab}}$ & 0.012 & $* *$ \\
\hline $\mathrm{C}_{20: 4 n-6}$ & $2.33^{\mathrm{a}}$ & $1.29^{\mathrm{c}}$ & $1.52^{\mathrm{b}}$ & $1.04^{\mathrm{d}}$ & $1.40^{\mathrm{bc}}$ & 0.053 & $* *$ \\
\hline $\mathrm{C}_{20: 5 \mathrm{n}-3}$ & - & $0.19^{\mathrm{a}}$ & $0.07^{\mathrm{c}}$ & $0.22^{\mathrm{a}}$ & $0.13^{b}$ & 0.013 & $* *$ \\
\hline $\mathrm{C}_{22: 5 n-3}$ & $0.07^{\mathrm{b}}$ & $0.19^{\mathrm{a}}$ & $0.22^{\mathrm{a}}$ & $0.23^{\mathrm{a}}$ & $0.24^{\mathrm{a}}$ & 0.021 & $* *$ \\
\hline $\mathrm{C}_{22: 6 \mathrm{n}-3}$ & $0.63^{c}$ & $3.42^{\mathrm{a}}$ & $1.90^{\mathrm{b}}$ & $3.24^{\mathrm{a}}$ & $1.95^{\mathrm{b}}$ & 0.095 & $* *$ \\
\hline$\sum$ saturated & $35.42^{\mathrm{a}}$ & $34.88^{a}$ & $31.88^{c}$ & $33.04^{b}$ & $30.72^{d}$ & 0.384 & $* *$ \\
\hline$\sum$ omega-3 & $1.47^{\mathrm{e}}$ & $4.66^{\mathrm{d}}$ & $5.56^{\mathrm{c}}$ & $7.43^{b}$ & $9.16^{\mathrm{a}}$ & 0.219 & $* *$ \\
\hline$\sum$ omega- 6 & $21.41^{\mathrm{a}}$ & $17.58^{b}$ & $18.68^{b}$ & $18.08^{b}$ & $20.84^{\mathrm{a}}$ & 0.595 & $* *$ \\
\hline$\sum$ omega-6/omega-3 & $14.56^{\mathrm{a}}$ & $3.77^{\mathrm{b}}$ & $3.36^{\mathrm{b}}$ & $2.43^{\mathrm{c}}$ & $2.28^{\mathrm{c}}$ & 0.202 & $* *$ \\
\hline
\end{tabular}

C: Control: without fish oil and flax seed; FO: with $1.5 \%$ fish oil; FS1: with $4.32 \%$ flax seed; FO+FS: with $1.5 \%$ fish oil + $4.32 \%$ flax seed; FS2: with $8.64 \%$ flax seed

$1 \%$ of total fatty acid; a,e Row means with common superscripts do not differ $(\mathrm{P}>0.05)$

$* * \mathrm{P}<0.01 ; * \mathrm{P}<0.05 ;$ NS - not significant $(\mathrm{P}>0.05)$

Table 6 The effect of including fish oil (FO) and flax seed (FS) in a layer diet on serum parameters (mg/dL) of the hens

\begin{tabular}{lccc}
\hline Treatments & Trigliceride & Cholesterol & HDL \\
\hline C & 1467.67 & $127.33^{\mathrm{a}}$ & 38.00 \\
FO & 1401.17 & $119.67^{\mathrm{ab}}$ & 35.17 \\
FS1 & 1337.00 & $117.83^{\mathrm{ab}}$ & 37.50 \\
FO+FS & 1417.83 & $105.50^{\mathrm{b}}$ & 39.00 \\
FS2 & 1348.00 & $99.67^{\mathrm{b}}$ & 40.83 \\
SEM & 111.55 & 6.719 & 2.21 \\
\hline \multicolumn{2}{l}{ Treatment } & Significance & \\
\hline C: & NS & $*$ & NS \\
\hline
\end{tabular}

C: Control: without fish oil and flax seed; FO: with $1.5 \%$ fish oil; FS1: with $4.32 \%$ flax seed; FO+FS: with $1.5 \%$ fish oil + $4.32 \%$ flax seed; FS2: with $8.64 \%$ flax seed

a,b Column means with common superscripts do not differ $(\mathrm{P}>0.05)$

$* \mathrm{P}<0.05 ; \mathrm{NS}$ - not significant $(\mathrm{P}>0.05)$

$\mathrm{SEM}=$ standard error of the means 
Inclusion of FO and FS in the diet did not affect $(\mathrm{P}>0.05)$ the triacylglycerol and HDL cholesterol concentrations of the serum of the hens. Supplementation with $1.5 \%$ FO+4.32 FS and $8.64 \%$ FS to diets decreased $(\mathrm{P}<0.05)$ serum cholesterol concentration (Table 6). Our finding was similar to that of Van Elswyk et al. (1994) who demonstrated that dietary FO supplementation at a 3.0\% inclusion level resulted in a decreased serum cholesterol concentration in hens.

Table 7 The effect of including fish oil (FO) and flax seed (FS) in the diet on egg production (\%), feed intake $(\mathrm{g} / \mathrm{hen} /$ day) and feed conversion ( $\mathrm{g}$ feed/g eggs) of hens

\begin{tabular}{lccc}
\hline Treatments & $\begin{array}{c}\text { Egg production } \\
\%^{2}\end{array}$ & $\begin{array}{c}\text { Feed intake } \\
\text { g/hen/day }\end{array}$ & $\begin{array}{c}\text { Feed conversion } \\
\text { g feed/g eggs }\end{array}$ \\
\hline C & $84.75^{\mathrm{bc}}$ & 110.11 & 2.06 \\
FO & $87.35^{\mathrm{ab}}$ & 110.49 & 2.00 \\
FS1 & $89.28^{\mathrm{a}}$ & 110.50 & 1.95 \\
FO+FS & $84.21^{\mathrm{bc}}$ & 114.95 & 2.04 \\
FS2 & $82.44^{\mathrm{c}}$ & 111.23 & 2.13 \\
SEM & 1.149 & 2.023 & 0.040 \\
\hline \multicolumn{2}{c}{ Significance } \\
\hline Treatment & $* *$ & $\mathrm{NS}$ & NS \\
\hline
\end{tabular}

C: Control: without fish oil and flax seed; FO: with 1.5\% fish oil; FS1: with 4.32\% flax seed; FO+FS: with $1.5 \%$ fish oil + $4.32 \%$ flax seed; FS2: with $8.64 \%$ flax seed

a,b, c: Column means with common superscripts do not differ $(\mathrm{P}>0.05)$

$* * \mathrm{P}<0.01$, NS - not significant $(\mathrm{P}>0.05)$

Table 8 The effect of including fish oil (FO) and flax seed (FS) in a diet on egg quality criteria

\begin{tabular}{|c|c|c|c|c|c|c|c|c|c|}
\hline Treatments & $\begin{array}{c}\text { Egg } \\
\text { weight } \\
\text { g }\end{array}$ & $\begin{array}{c}\text { Yolk } \\
\text { weight } \\
\text { g }\end{array}$ & $\begin{array}{c}\text { Yolk } \\
\text { ratio } \\
\% \\
\end{array}$ & $\begin{array}{c}\text { Albumen } \\
\text { weight } \\
\text { g } \\
\end{array}$ & $\begin{array}{c}\text { Albumen } \\
\text { ratio } \\
\% \\
\end{array}$ & $\begin{array}{c}\text { Shell } \\
\text { weight } \\
\mathrm{g} \\
\end{array}$ & $\begin{array}{c}\text { Shell } \\
\text { ratio } \\
\% \\
\end{array}$ & $\begin{array}{c}\text { Shell } \\
\text { strength } \\
\mathrm{kg} / \mathrm{cm}^{2}\end{array}$ & $\begin{array}{c}\text { Shell } \\
\text { thickness } \\
\text { mm }\end{array}$ \\
\hline $\mathrm{C}$ & 63.21 & 15.71 & 24.85 & 41.18 & 65.18 & 6.32 & 10.00 & 2.64 & 0.410 \\
\hline FO & 62.46 & 15.76 & 25.23 & 40.38 & 64.65 & 6.32 & 10.12 & 2.44 & 0.416 \\
\hline FS1 & 62.69 & 15.88 & 25.33 & 40.74 & 64.99 & 6.07 & 9.68 & 2.62 & 0.396 \\
\hline $\mathrm{FO}+\mathrm{F} 1$ & 64.37 & 16.04 & 24.92 & 41.93 & 65.14 & 6.40 & 9.94 & 2.53 & 0.411 \\
\hline FS2 & 63.41 & 15.98 & 25.20 & 41.34 & 65.19 & 6.09 & 9.60 & 2.44 & 0.408 \\
\hline SEM & 1.54 & 0.336 & 0.461 & 0.848 & 0.499 & 0.128 & 0.169 & 0.212 & 0.006 \\
\hline Phase 1 & $62.27^{b}$ & $15.47^{b}$ & 24.84 & 40.53 & 65.09 & 6.27 & $10.07^{\mathrm{a}}$ & 2.65 & 0.411 \\
\hline Phase 2 & $64.19^{a}$ & $16.28^{\mathrm{a}}$ & 25.36 & 41.70 & 64.96 & 6.21 & $9.67^{b}$ & 2.41 & 0.406 \\
\hline SEM & 0.667 & 0.213 & 0.292 & 0.537 & 0.316 & 0.451 & 0.107 & 0.134 & 0.004 \\
\hline \multicolumn{10}{|c|}{ Significance } \\
\hline Treatment & NS & NS & NS & NS & NS & NS & NS & NS & NS \\
\hline Phase & $*$ & $* *$ & NS & NS & NS & NS & $*$ & NS & NS \\
\hline Treatment $\mathrm{x}$ Phase & NS & NS & NS & NS & NS & NS & NS & NS & NS \\
\hline
\end{tabular}

C: Control: without fish oil and flax seed; FO: with $1.5 \%$ fish oil; FS1: with $4.32 \%$ flax seed; FO+FS: with $1.5 \%$ fish oil + $4.32 \%$ flax seed; FS2: with $8.64 \%$ flax seed

${ }^{\mathrm{a}, \mathrm{b}}$ Column with common superscript do not differ $(\mathrm{P}>0.05)$

$* * \mathrm{P}<0.01 ; * \mathrm{P}<0.05 ; \mathrm{NS}$ - not significant $(\mathrm{P}>0.05)$

While adding FO to the diet did not cause a significant difference in egg production, $4.32 \% \mathrm{FS}$ supplementation increased egg production $(\mathrm{P}<0.01)$ compared to hens receiving $8.64 \% \mathrm{FS}, 4.32 \% \mathrm{FS}+$ $1.5 \% \mathrm{FO}$ and the control (Table 7). This finding is similar to that of Hargis et al. (1991) who determined that FO was not effective in egg production. Jiang et al. (1991), who included FS at a $15 \%$ level and Yannokopoulos et al. (1999), who used FS at levels of 5, 10 and 15\% reported that FS did not effect egg production. However, Scheideler \& Froning (1996) reported that 1.5\% FO and 5, 10 and 15\% FS increased egg production significantly $(\mathrm{P}<0.05)$. Feed intake and feed conversion were not affected by any of the treatments. From the egg quality criteria determined, only egg and yolk weights increased significantly with the age of the hen (Table 8). 
Feeding dietary FO and FS did not affect $(\mathrm{P}>0.05)$ the determined egg quality criteria. This finding is similar to those of other researchers (Voght \& Harnisch, 1978; Roland, 1979; Hurtwitz, 1987; Basmacioğlu \& Ergül, 2000). Yannakopoulos et al. (1999) reported that FS used in laying hen diets did not affect egg quality criteria except for egg and yolk weights. Only one mortality occurred, and that amongst the hens receiving the $1.5 \mathrm{FO}+4.32 \mathrm{FS}$ diet.

\section{Conclusions}

The results of the present study show that adding FO and FS to the diets of laying hens resulted in up to a 6 fold increase in total omega- 3 fatty acids concentration of yolk and a decrease in omega-6/omega-3 ratio of yolk compared to the control. In addition, these supplements did not affect the performance of hens and egg quality criteria adversely. Therefore, it is possible to obtain yolk containing satisfactory amounts of beneficial fatty acids by supplementing the diets with fish oil and flax seed.

\section{Acknowledgements}

This project was supported by Scientific Research Foundation of Ege University, Turkey (98ZRF-

\section{References}

Anonymous, 1991. Animal feeds-metabolizable energy method (Chemical Method). T.S.E. Ts 9610/ December, Ankara.

AOAC, 1990. Official methods of analysis (15th ed.). Association of Official Analytical Chemists, Inc., Washington DC, USA.

Basmacioğlu, H. \& Ergül, M., 2000. A research on the factors affecting cholesterol content and some other characteristics of egg in laying hens. 1. The Effect of age on cholesterol content and some other characteristics of egg. Int. Anim. Nutr. Congr. 2000. 4-6 September, Isparta/Turkey.

Bhatnagar, D. \& Durrington, P.N., 2003. Omega-3 fatty acids: their role in the prevention and treatment of atherosclerosis related risk factors and complications. Int. J. Clin. Pract. 57, 305-14.

Blanch, A. \& Grashorn, M.A., 1995. Ernährungsphysiologische Bedeutung der Omega-3- Fettsäuren und Möglichkeiten der Anreicherung in Eiern. Physiological importance of omega-3 fatty acids for human nutrition and ways for their enrichment in eggs. Archive Für Geflügelkunde 60, 49-58.

Brendl, J., Kruparova, M. \& Kminke, M., 1979. Trends in and prospects for cholesterol concentration in hens eggs on a worldwide scale. Food Sci. Technol., Abstr. 15, 7Q92.

Caston, L. \& Leeson, S., 1990. Research Note: Dietary flax and egg composition. Poult. Sci. 69, 1617-1620.

Cherian, G. \& Sim, J.S., 1991. Effect of feeding full fat flax and canola seeds to laying hens on the fatty acid composition of eggs, embryos, and newly hatched chicks. Poult. Sci. 70, 917-922.

Coetzee, G.J.M. \& Hoffman, L.C., 2002. Effects of various dietary n-3/n-6 fatty acid ratios on the performance and body composition of broilers. S. Afr. J. Anim. Sci. 32, 175-184.

Erkkila, A.T., Lehto, S., Pyorala, K. \& Uusitupa, M.I., 2003. n-3 Fatty acids and 5-y risks of death and cardiovascular disease events in patients with coronary artery disease. Am. J. Clin. Nutr. 78, 65-71.

Gissel, C., Lindfeld, A. \& Ehnenbrink, H.L., 1976. Effects of breed, age and diet of hens on the cholesterol content of the egg yolk. Food Sci. Technol., Abstr. 9, 2 Q20.

Gonzalez-Esquerra, R. \& Leeson, S., 2000. Effect of feeding hens regular or deodorized menhaden oil on production parameters, yolk fatty acid profile, and sensory quality of eggs. Poult. Sci. 79, 1597-1602.

Hammershøj, M., 1997. Effect of dietary vegetable oils for egg laying hens on yolk fatty acid composition and other quality traits in a phase feeding program, 292-298, Proc. VII European Symp. Quality of Eggs and Egg Products, 21-26 September, Poznan, Poland. 366 pp.

Hargis, P.S., Van Elswyk, M.E. \& Hargis, B.M., 1991. Dietary modification of yolk lipid with menhaden oil. Poult. Sci. 70, 874-883.

Herber S.M. \& Van Elswyk, M.E., 1996. Dietary marine algae promote efficient deposition of n-3 fatty acids for the production of enriched shell eggs. Poult. Sci. 75, 1501-1507.

Hurtwitz, S., 1987. Effect on nutrition in egg quality, 235-254. In: Egg quality, current problems and recent advances. Eds. Wells, R.G. \& Belgavin, C.G., CARFAX Publishing Company, England. 302 pp.

Jiang, Z., Ahn, D.U. \& Sim, J.S., 1991. Effects of feeding flax and two types of sunflower seeds on fatty acid compositions of yolk lipid classes. Poult. Sci. 70, 2467-2475. 
Joseph, D.J. \& Ackman, R.G., 1992. Capillary column gas chromatographic method for analysis of encapsulated fish oils and fish oils methyl esters. J. AOAC. 75, 488-506.

Komprda, T., Zelenka, J., Bakaj, P., Kladroba, D., Blazkov, E. \& Fajmonova, E., 2003. Effect of dietary sunflower, linseed or fish oil on cholesterol and fatty acid content in turkey meat, 185-191, Proc. XVI European Symp. Quality of Poultry Meat, 23-26 September, France. 476 pp.

Leskanich, C.O., \& Noble, R.C., 1997. Manipulation of the n-3 polyunsaturated fatty acid composition of avian eggs and meat. World's Poult. Sci. 53, 157-183.

Lewis, N.M., Seburg, S. \& Flanagan, N.L., 2000 Enriched eggs as a source of N-3 polyunsaturated fatty acids for humans. Poult. Sci. 79, 971-974.

Lin , J.H. \& Pratt, D.E., 1992. Effect of menhaden oil on cholesterol of the egg. Poult. Sci., 71, Suppl. 1.

Meluzzi, A., Tallarico, N., Sirri, F., Cristofori, C. \& Giordani, G., 1997a. Fortification of hen eggs with N-3 polyunsaturated fatty Acids, 270-277. Proc. VII European Symp. Quality of Eggs and Egg Products, 21-26 September, Poznan, Poland. 366 pp.

Meluzzi, A., Tallarico, N., Sirri, F. \& Franchini, A., 1997b. Influence of hen diets supplemented with refined fish oil on the bird productive traits and on the cholesterol level and sensory quality of the eggs, 45-51, Proc. VII European Symp. quality of eggs and egg products, 21-26 September, Poznan, Poland. 366 pp.

Meluzzi, A., Sirri, F. Manfreda, G., Talarico, N. \& Franchini, A., 2000. Effects of dietary vitamin E on the quality of table eggs enriched with n-3 long-chain fatty acids. Poult. Sci., 79,539-545.

Meyer, B.J., Mann, N.J., Lewis, J.L., Milligan, G.C., Sinclair, A.J. \& Howe, P.R., 2003. Dietary intakes and food sources of omega- 6 and omega-3 polyunsaturated fatty acids. Lipids 38, 391-398.

Naumann, C. \& Bassler, R., 1993. Die chemiche untersuchung von Futtermitteln. Methodenbuch, Band. 3. Erg., VDLUFA-Verlag, Darmstadt.

Niemiec, J., Stepinska, M., Swierezewska, E., Riedel, J., Kakowska, R., Siennicka, A. \& Grzyboska, A., 1997. Effect of diet on fatty acid composition in the egg, 239-243. Proc. VII European Symp. Quality of Eggs and Egg Products, 21-26 September, Poznan, Poland. 366 pp.

Oltjen, R.R. \& Dinius, D.A., 1975. Production that alter composition of foods of animal origin. J. Anim. Sci. 41, 703-722.

Poyraz, Ö., 1987. Egg yolk cholesterol levels in chicken and Japanese quail, A. Ü. Veteriner Fakültesi Dergisi 34 (1), 143-154.

Roland, D.A., 1979. Factors Influencing Shell Quality of Aging Hens. Poult. Sci. 58, 774-777.

SAS, 1985. Statistical Analysis Systems user's guide (5th ed.). SAS Institute Inc., Raleigh North Carolina.

Scheideler, S.E. \& Froning, G.W., 1996. The combined influence of dietary flax seed variety, level, form and storage conditions on egg production and composition among vitamin E-supplemented hens. Poult. Sci. 75, 1221-1226.

Simopoulos, A.P., 2000a. Symposium: Role of poultry products in enriching the human diet with n-3 PUFA. Poult. Sci. 79, 961-970

Simopoulos, A.P., 2000b. Human requirement for N-3 polyunsaturated fatty acids. Poult. Sci. 79, 961-970.

Van Elswyk, M. E., Hargis, B.M., Williams, J. D. \& Hargis, P.S., 1994. Dietary menhaden oil contributes to hepatic lipids in laying hens. Poult. Sci. 73, 653-662.

Voght, H. \& Harnisch, S., 1978. Einflüsse verschiedener phosphor-und natriumgehalte im legehennenfutter auf leistungen und eischalenqualität. Archive für Geflügelkunde 42, 169-173.

Yannakopoulos, A.L., Tserveni, A.S. \& Yannakakis, S., 1999. Effect of feeding flax seed to laying hens on the performance and egg quality and fatty acid composition of egg yolk. Archive für Geflügelkunde 63, 260-263.

Zeidler, G., 1998. Poultry Products in the $21^{\text {st }}$ Century, $132-141$. The poultry industry towards the $21^{\text {st }}$ Century, WPSA-Israel Branch 10 ${ }^{\text {th }}$ European Poult. Conf., Proc. Vol. 1, Jerusalem, Israel. 502 pp. 